\title{
Family Studies and Aetiology of Club Foot
}

\author{
RUTH WYNNE-DAVIES
}

\begin{abstract}
From the Medical Research Council, Research Group on Genetic Problems in Orthopaedic Disease, Department of Orthopaedic Surgery, University of Edinburgh
\end{abstract}

Congenital club foot and talipes are used to describe various abnormalities of the foot in the newborn child. The most serious of these is talipes equinovarus in which there is plantar flexion of the ankle and inversion of the foot. This deformity is difficult to treat, having a marked tendency to recur, and causes a real disability. About half the cases are bilaterally affected. Patients frequently attend hospital for the first IO-I5 years of life. A long-term follow up of the results of treatment of patients with talipes equinovarus has been reported elsewhere (WynneDavies, 1964a). The family findings in a series of patients with talipes equinovarus, mild (postural) talipes equinovarus, talipes calcaneo-valgus, and metatarsus varus have been reported in summary form (Wynne-Davies, 1964b). In this paper the family data, especially that on talipes equinovarus, are presented and discussed in more detail. Cases secondary to spina bifida, cerebral palsy, and arthrogryposis are not included.

\section{Subjects and Method}

The present study is based on patients attending the Princess Elizabeth Orthopaedic Hospital, Exeter, who were born in 1940-61.

This Orthopaedic Hospital serves the greater part of the largely rural county of Devon (excluding the Plymouth area), and there is available a stable population, making the tracing of families relatively easy, The orthopaedic service is based on the hospital at Exeter, and out-patient clinics are held at intervals of one, two, or four weeks throughout the county-at Exeter, Torquay, Newton Abbot, Okehampton, Barnstaple, Bideford, Honiton, and Tiverton. Patients attending currently for treatment during $196 \mathrm{I}$ were seen at one of their routine visits to a clinic. Former patients were first approached by letter and were then seen at the outlying clinic which they had previously attended. A family history was taken from the individual, or where more appropriate, a parent, and nearly all affected relatives were personally examined. (Details of families with an affected first-degree relative are

Received February 22, 1965. given in Appendix A.) In the only two instances where an affected first-degree relative was not seen personally, there was reliable medical evidence of the deformity (Index patients 30 and 108). Relatives stated to be normal were not specially examined, though in fact many were seen, as they attended with the patient. In the case of talipes equinovarus, with the standard of school and other medical services easily available in this country, it is most unlikely that such a severe deformity would pass unnoticed or ignored, and the ascertainment of affected relatives will be nearly complete. In the case of postural talipes equinovarus, talipes calcaneo-valgus, and metatarsus varus, relatives were not examined since these deformities almost invariably disappear and retrospective diagnosis is not possible. Only those cases confirmed by medical evidence have been classed as affected, but obviously many cases never reach hospital, and the ascertainment of affected relatives will be incomplete.

For talipes equinovarus, 163 case sheets were available for patients born from 1940 to $196 \mathrm{I}$. Of these, 144 were traced of whom 133 were seen personally and II replied to questionnaires. Of the remaining I9, I3 were not traced, 2 were foster children, and 4 refused to co-operate. Index patients with the three other common forms of talipes were those born between 1948 and I96I; 31 patients were traced with postural equinovarus, 74 with talipes calcaneo-valgus, and 72 with metatarsus varus.

\section{Results}

Incidence. Since the Princess Elizabeth Orthopaedic Hospital is the only orthopaedic hospital in the area and both private and National Health Service patients have been included, ascertainment of cases needing hospital treatment will be nearly complete. Comparing the numbers of patients with the Registrar General's figures for all live births in the area over the same period, the incidences of the different forms of the malformation were: talipes equinovarus-I.24 per 1000 live births (males $\mathrm{I} \cdot 62$ per I000, females 0.80 ); postural talipes equinovarus- -.50 per 1000 live births (males 0.24 per 1000 , females 0.78 ); talipes calcaneo-valgus-I.09 per 1000 live births (males 0.07 per 1000, females 0.33 ); meta- 
tarsus varus-I.2I per I000 live births (males I.02 per 1000, females $0 \cdot 19$ ).

The total incidence, 4.04 per rooo live births, is very similar to McKeown and Record's (I960) finding of 4 per rooo total births in their Birmingham survey, but in their survey the types were not differentiated. The figure for the most serious malformation, talipes equinovarus, $1 \cdot 24$ per 1000 live births, is very similar to that recorded from Sweden of I per 1000 live births (Hilsonner, I927, cited by Böök, I948).

Associated Malformations. The malformations associated with club foot have been presented in detail elsewhere (Wynne-Davies 1964b). They fall into two groups.

(a) Minor defects of connective tissue in patients with talipes equinovarus and calcaneo-valgus, such as generalized joint laxity (present in over 10\% of patients with talipes equinovarus and talipes calcaneo-valgus) and inguinal hernia (present in $7 \%$ of boys with talipes equinovarus and talipes calcaneo-valgus).

(b) Minor deformities of the extremities such as syndactyly, polydactyly, oligodactyly, and ring constrictions of fingers (present in $4.5 \%$ of patients with talipes equinovarus, talipes calcaneo-valgus, and metatarsus varus). Patients with talipes calcaneo-valgus show the recognized association of this malformation with congenital dislocation of the hip ( $5 \%)$.

Sex Ratio. 97 of the 144 patients with talipes equinovarus were male, giving a sex ratio of $2 \cdot I$. Most authors have also reported a sex incidence of about 2. In contrast, 35 of the 46 patients with postural talipes equinovarus were girls, giving a sex ratio of 0.31 . Of the roo patients with talipes calcaneo-valgus, 60 were girls, giving a sex ratio of 0.66 . Of the III patients with metatarsus varus, 62 were girls, giving a sex ratio of 0.79 .

Maternal Age and Birth Order Effects. No parental age or birth order effect was found for talipes equinovarus. The analysis of the 94 cases of talipes equinovarus born between 1948 and 1960 is shown in Table I. The mean maternal age was 26.0 years and the mean paternal age 28.8 years. Similarly, no parental age or birth order effects were found for postural talipes equinovarus or with metatarsus varus (WynneDavies, 1964b). In contrast, with talipes calcaneovalgus there was a highly significant excess of first-born children in comparison with the general
TABLE I

TALIPES EQUINOVARUS

BIRTH ORDER AND MATERNAL AGE-COMPAREDP WITH NATIONAL FIGURES FOR ENGLAND AND WALES: DEVON BIRTHS 1948-1960

\begin{tabular}{|c|c|c|c|c|c|}
\hline Maternal Age & $15-24$ & $25-29$ & $30-34$ & $35+$ & Total \\
\hline $\begin{array}{l}\text { Index cases } \\
\text { General population }\end{array}$ & $\begin{array}{l}29 \\
31 \cdot 54\end{array}$ & $30 \cdot 64$ & $\begin{array}{c}22 \\
19 \cdot 01\end{array}$ & $\begin{array}{c}10 \\
12.82\end{array}$ & 94 \\
\hline
\end{tabular}

$\chi^{3}(s)=1.48 ; p>0.10$. Not significant

\begin{tabular}{|c|c|c|c|c|c|}
\hline Previous Children & $\circ$ & $\mathbf{r}$ & 2 & $3+$ & Total \\
\hline $\begin{array}{l}\text { Index cases } \\
\text { General population }\end{array}$ & $\begin{array}{c}45 \\
37 \cdot 19\end{array}$ & $\begin{array}{c}23 \\
28 \cdot 75\end{array}$ & $\begin{array}{r}17 \\
14 \cdot 28\end{array}$ & $13^{9} \cdot 78$ & 94 \\
\hline
\end{tabular}

$\chi^{2}(s)=4.97 ; p>0.10$. Not significant.

population. This is shown in Table II. Therd was also an excess of children born to younger ${ }_{0}$ mothers, but this is probably coincidental to the? birth order effect.

TABLE II

TALIPES CALCANEO-VALGUS

BIRTH ORDER AND MATERNAL AGE-COMPARISONWITH NATIONAL FIGURES FOR ENGLAND AND WALES DEVON BIRTHS 1948-1960

\begin{tabular}{c|c|c|c|c|}
\hline \multicolumn{1}{c|}{ Maternal Age } & $15-24$ & $25-29$ & $30-34$ & $35+\frac{2}{2} \cdot$ \\
\hline $\begin{array}{l}\text { Index cases } \\
\text { General population }\end{array}$ & $21 \cdot 14$ & $20 \cdot 53$ & $12 \cdot 74$ & $8 \cdot 59$ \\
\hline
\end{tabular}

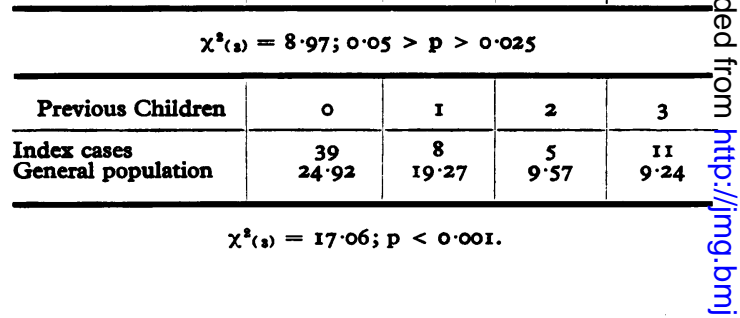

Parental Consanguinity. In no instance in the whole series of 347 cases was there parentaB consanguinity.

Findings in Relatives.
Twins. One boy and one girl index patient with talipes equinovarus had monozygotic co-twinso who were unaffected (the male twins were con- 0 cordant for blood groups $\mathrm{A}, \mathrm{CDE} / \mathrm{cde}, \mathrm{MN}$, N $\mathrm{K}-, \mathrm{P}+, \mathrm{Fy}^{\mathrm{a}}$; the female twins were not grouped). $\mathrm{O}$ One boy with talipes equinovarus had a dizygotic twin brother (differing in Rhesus group) who was? also an index patient with postural talipes equino- $-\infty$ varus. One girl index patient with talipes calcaneo- 
valgus had an unaffected dizygotic twin sister (differing in Kell types). A girl index patient with metatarsus varus had a probable monozygotic twin sister (not grouped) who was unaffected.

These twins have been included among the sibs in the following section.

First-degree Relatives. The findings on the parents and brothers and sisters of the talipes equinovarus patients are shown in Table III and those of the other three groups in Appendix B.

TABLE III

TALIPES EQUINOVARUS, 1940-6I GROUP: FIRST-DEGREE RELATIVES

\begin{tabular}{|c|c|c|c|c|}
\hline & Father & Mother & Brothers & Sisters \\
\hline $\begin{array}{c}\text { Male index } \\
97\end{array}$ & 97 & 97 & $\begin{array}{c}115 \\
(4) \\
(\mathrm{MV})\end{array}$ & (I $\frac{90}{\mathrm{MV}}$ \\
\hline $\begin{array}{c}\text { Female index } \\
47\end{array}$ & $\begin{array}{l}47 \\
\text { (3) }\end{array}$ & (I $\left.\frac{47}{\mathrm{CV}}\right)$ & $\begin{array}{r}33 \\
(2)\end{array}$ & $\begin{array}{l}34 \\
(\mathrm{2}) \\
(\mathrm{I})\end{array}$ \\
\hline${ }_{144}$ & $\begin{array}{r}144 \\
(4)\end{array}$ & $\left(\mathrm{I} \frac{144}{\mathrm{CV}}\right)$ & $\begin{array}{c}148 \\
(6) \\
(1 \stackrel{M}{M})\end{array}$ & $\begin{array}{c}124 \\
(2) \\
(2 \mathrm{MV})\end{array}$ \\
\hline
\end{tabular}

Those with the same deformity shown in brackets; calcaneo-valgus (CV) and metatarsus varus (MV) are also shown.

For all index patients with talipes equinovarus the over-all proportion of first-degree relatives affected with the same malformation was 12 in $560,2 \cdot 14 \%$. For male index patients, I of 97 fathers, 4 of II 5 brothers, but no mother, and none of 90 sisters were affected. For female index patients, 3 of 47 fathers, 2 of 33 brothers, no mother, but 2 of 34 sisters were affected. Thus, for male index patients 5 of $212(2.3 \%)$ of male and 0 of I87 female first-degree relatives were affected. For female index patients, 5 of $80(6.2 \%)$ of male and 2 of $81(2.5 \%)$ of female first-degree relatives were affected. If relatives of both sexes are combined, the higher proportion of affected relatives of female index patients is significant at the $5 \%$ level. The index patients were too young to have children but in a further series of patients born before 1940, 35 male index patients had 0 of I6 sons and 1 of 13 daughters similarly affected; and 12 female index patients had 0 of 8 sons and 0 of 5 daughters similarly affected. In addition, I relative had calcaneo-valgus and 3 had metatarsus varus.

In the small number, 113 , of first-degree relatives of patients with postural talipes equinovarus, 3 $(2.65 \%)$ were similarly affected, but in addition it is interesting that I relative had talipes equinovarus and 2 had talipes calcaneo-valgus.

Of the 258 first-degree relatives of patients with talipes calcaneo-valgus, $8(3 \cdot 10 \%)$ were similarly affected. Of 263 first-degree relatives of patients with metatarsus varus, $5(\mathrm{I} \cdot 8 \mathrm{I} \%)$ had a similar malformation, and in one of these the metatarsus deformity was combined with equinovarus. In addition, 3 of the relatives had talipes equinovarus.

Second-and Third-degree Relatives. The findings on aunts and uncles and on first cousins of talipes equinovarus index patients are set out in Table IV.

The over-all proportion of aunts and uncles with the same malformation is 5 in $823(0.61 \%)$ and of first cousins, 2 in 991 ( $0.20 \%)$.

Malformations Other Than Those of Central Nervous System. The incidence of other malformations in relatives appears to be no more than the random incidence, except that patients with talipes equinovarus and talipes calcaneo-valgus had relatives affected by other conditions that are associated with generalized joint laxity (Carter and Sweetnam, 1960; Carter and Wilkinson, 1964); two mothers of talipes equinovarus patients

TABLE IV

TALIPES EQUINOVARUS: SECOND AND THIRD DEGREE RELATIVES

\begin{tabular}{|c|c|c|c|c|c|c|c|c|}
\hline & \multicolumn{4}{|c|}{ Uncles and Aunts } & \multicolumn{2}{|c|}{ Paternal Cousins } & \multicolumn{2}{|c|}{ Maternal Cousins } \\
\hline & \multicolumn{2}{|c|}{ Father's } & \multicolumn{2}{|c|}{ Mother's } & \multirow{2}{*}{ Male } & \multirow{2}{*}{ Female } & \multirow{2}{*}{ Male } & \multirow{2}{*}{ Female } \\
\hline & Brothers & Sisters & Brothers & Sisters & & & & \\
\hline $\begin{array}{l}\text { 1940-6I group } \\
\text { Male } \\
\text { Female }\end{array}$ & $\begin{array}{r}143 \\
80(I)\end{array}$ & $\begin{array}{r}130 \\
53 \\
\end{array}$ & $\begin{array}{r}143 \\
58 \\
\end{array}$ & $\begin{array}{r}\text { I } 52(2) \\
64(2)\end{array}$ & $\begin{array}{r}172 \\
73 \\
\end{array}$ & $\begin{array}{r}181 \\
70 \\
\end{array}$ & $\begin{array}{c}169(2) \\
93\end{array}$ & $\begin{array}{r}168 \\
66 \\
\end{array}$ \\
\hline Total & $223(I)$ & 183 & 201 & $216(4)$ & 245 & 250 & $262(2)$ & 234 \\
\hline
\end{tabular}

Those with the same deformity shown in brackets. 
had congenital dislocation of the hip; one mother of a talipes calcaneo-valgus patient (who also had recurrent dislocation of the patella) had congenital dislocation of the radial heads; a brother of another patient had congenital dislocation of the hip; and a sister of yet another patient had recurrent subluxation of the shoulders.

\section{Discussion}

The admirable twin study by Idelberger (1939) showed that both genetic and environmental factors were concerned in the development of talipes equinovarus. He found that there were I3 of 40 monozygotic twins $(32.5 \%)$ of patients, and 4 of 134 dizygotic co-twins (2.9\%) also affected.

This study shows a substantial familial concentration for patients with talipes equinovarus, and confirms the evidence from twins that genetic factors are important in the aetiology of the condition. Over-all incidence in parents and sibs of patients with talipes equinovarus, of 12 in 560 , or $2 \cdot 14 \%( \pm 0.62)$, is about 17 times the population incidence of $0.124 \%$. The over-all incidence in aunts and uncles of 5 in 823 , or $0.61 \%$, is about 6 times the population incidence, and that in cousins, 2 in 991 , is very close to the population incidence.

These relative incidences would be compatible with the hypothesis of genetic predisposition to talipes equinovarus by a dominant gene with a low rate of manifestation. It is, however, much more likely that the genetic predisposition is multifactorial. One element in this predisposition is probably a genetically determined generalized joint laxity, which was found in a substantial proportion of patients and often behaves as if due to a dominant mutant gene (Carter and Sweetnam, 1958), and also predisposes to such abnormalities as congenital dislocation of the hip, recurrent dislocation of the shoulder, and dislocation of the radial heads, which in this series were found in the first-degree relatives of index patients.

The family findings in the other three conditions are also probably best explained in terms of multifactorial genetic predisposition with an important environmental component. The increase observed in the incidence in first-degree relatives compared to that in the general population is about thirtyfold for talipes calcaneo-valgus, fiftyfold for postural equinovarus, and about fifteenfold for talipes metatarsus varus.
The family findings suggest a relationship of talipes equinovarus with metatarsus varus, buf much less clearly with calcaneo-valgus; the mil@? postural talipes equinovarus appears to have links: with calcaneo-valgus. Familial generalized joinf laxity could be the link between talipes equinovaru? and calcaneo-valgus, and a mild connective tissue abnormality could account for the association of both these conditions with joint laxity and inguina\& hernia. Some other mechanism must be involved for the relationship between equinovarus and metatarsus varus, since in the latter there is no association with joint laxity or with inguinal hernia $\vec{\omega}$

There are no indications yet of the environmentaP factors involved, but intrauterine posture is likel to be important. The intrauterine posture, which Wilkinson (Wilkinson, 1963) has suggested is important for congenital dislocation of the hipi namely flexed hips, extended knees, and externally rotated feet, may predispose to calcaneo-valgus as well and accounts for the association between the two conditions, and it is noteworthy that there is an excess of first-born in both congenital dislocation of the hip and calcaneo-valgus.

I am glad to acknowledge the support I have received. from the South Western Regional Hospital Board and the staff of the Princess Elizabeth Orthopaedic Hospicals Exeter, and in particular the help given by $\mathrm{Mr}$. Norming Capener, Mr. G. Blundell Jones, and Mr. F. C. Durbo

Thanks are due to Dr. F. Oliver, Exeter Universitys for help with statistics, and to Dr. Cedric Carter of the Medical Research Council, Clinical Genetics Research Unit, Institute of Child Health, London, who firs? suggested the possibility of an associated joint laxitye and without whose guidance this paper could not have been written.

\section{REFERENCES}

Carter, C., and Sweetnam, R. (1958). Familial joint laxity and recurrent dislocation of the patella. F. Bone ft Surg., 40B, 664 . , and - (1960). Recurrent dislocation of the patella and of the shoulder. ibid., 42B, $72 \mathrm{I}$.

, and Wilkinson, J. A. (1964). Persistent joint laxity and con $=\frac{\sigma}{3}$ genital dislocation of the hip. ibid., 46B, 40 .

Hilsonner, I. (1927). Cited by Böök, J. A. (1948). A contributior to the genetics of congenital clubfoot. Hereditas (Lund), 34, 2893 Idelberger, K. (1939). Die Ergebnisse der Zwillingsforschung beim angeborenen Klumpfuss. Verh. dtsch. orthop. Ges., 33, 272 음 McKeown, T., and Record, R. G. (r960). Malformations in a population observed for five years after birth. In Ciba Foundation Symposium on Congenital Malformations, G. E. W. Wolstenholme and C. M. O'Connor, J. and A. Churchill, London.

Wilkinson, J. A. (1963). Prime factors in the etiology of congenita dislocation of the hip. F. Bone ft Surg., 45B, 268.

Wynne-Davies, R. (I964a). Talipes equinovarus. ibid., 46B, 464 N (1964b). Family studies and the cause of congenital clubfoot ibid., 46B, 445 . 


\section{APPENDIX A}

\section{Details of Families in which a First-degree Relative is Affected with One of the Forms of Talipes, Calcaneo-valgus, and Metatarsus Varus}

Index patients are in italics; similarly affected sibs are marked with an asterisk; s.b. is stillborn; d. is died; twins are in square brackets; TEV is talipes equinovarus; PTEV is postural talipes equinovarus; MV is metatarsus varus; $\mathrm{CV}$ is calcaneo-valgus; $\mathrm{B}$. is bilateral; $\mathrm{L}$. is left; $R$. is right.

\begin{tabular}{|c|c|c|c|}
\hline \multirow[b]{2}{*}{ Case No. } & \multirow[b]{2}{*}{ Sibship } & \multicolumn{2}{|c|}{ Date of Birth } \\
\hline & & Mother & Father \\
\hline \multicolumn{4}{|c|}{ Talipes Equinovarus } \\
\hline $\begin{array}{l}\text { 15 (335 and } \\
302)\end{array}$ & $\begin{array}{l}\text { F (B.MV) } 5.49 ; M 8.50 ; M(B . T E V) 8.51 ; M 9.55 \\
{[M(B . M V) 4.57 ; F 4.57]}\end{array}$ & $5 \cdot 28$ & $4 \cdot 29$ \\
\hline 30 & $\begin{array}{l}M_{1} \cdot 48 ; M(L . T E V) 8.49 ; M \text { ro.50; F } 3.52 \\
M^{*}(\mathrm{~B} . \text { TEV }) 7.53 ; M ~ 8.55\end{array}$ & $10 \cdot 28$ & I I $\cdot 27$ \\
\hline 32 and 158 & 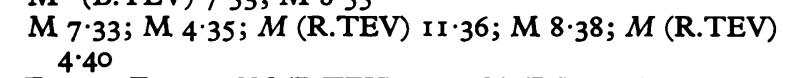 & $3 \cdot 09$ & $\mathbf{I} \cdot 03$ \\
\hline 53 (and 196) & F 6.52; F $4.54 ;[M$ (B.TEV) $5.61 ; M$ (B.PTEV) $5.6 \mathrm{I}]$ & $8 \cdot 27$ & I.25 \\
\hline & F 10.39; $M($ R.TEV) I2.58 & $9 \cdot 17$ & I2.I4 (R.TEV) \\
\hline 75 and 76 & $M(\mathrm{R}$.TEV) 10.40; $M$ (R.TEV) $8.42 ; M$ II.5I & I. 19 & 10.06 \\
\hline 108 & F $3.35 ; F$ (R.TEV) 5.45 & 9.10 & $5 \cdot 10$ (B.TEV) \\
\hline III and II & F 2.39; $F$ (R.TEV) 8.45; $F$ (R.TEV) 8.46 & $2 \cdot 25$ & $5 \cdot 22$ \\
\hline 118 & $F(B . T E V) 12.55 ;$ F $_{12} \cdot 56 ;$ M 6.59 & $5 \cdot 32(B . C V)$ & $3 \cdot 30$ \\
\hline 135 & $\mathrm{M}^{*}(\mathrm{~B} . \mathrm{TEV}) 7 \cdot 38 \cdot F(\mathrm{~B} . \mathrm{TEV}) 2 \cdot 40 \cdot \mathrm{F}$ 10.42; F 5.5I & $5 \cdot 14$ & 10.08 (B.TEV) \\
\hline I4I & $F($ R.TEV) $3.6 \mathrm{I}$ & I. 33 & $9 \cdot 33$ (R.TEV) \\
\hline I43 (and 368) & $\begin{array}{l}F \text { (R.TEV, L.MV) } 5.50\left[M^{*} \text { d. (B.TEV) } 10.52 ; M 10.52\right] \\
\text { F 6.54; F (R.MV) } 10.56 ; M{ }_{7.60}\end{array}$ & $5 \cdot 24$ & $\mathrm{I} \cdot \mathrm{I} 4$ \\
\hline \multicolumn{4}{|c|}{ Postural Talipes Equinovarus } \\
\hline $\begin{array}{l}194 \\
196\end{array}$ & $\begin{array}{l}M^{*} \text { (B.PTEV) } 12 \cdot 57 ; M \text { (B.PTEV) } 6.60 \\
\text { (See TEV No. } 53 \text { ) }\end{array}$ & $5 \cdot 36$ & $8 \cdot 35$ \\
\hline 199 & $M_{3.48 ; M} 4.49 ; F$ (B.PTEV) 3.52 & II $\cdot 25$ & $2 \cdot 23($ B.CV) \\
\hline 205 & $F$ (B.PTEV) 3.57 ; F 10.60 & 4.38 (B.CV) & $3 \cdot 31$ \\
\hline 208 & F I.50; $F$ (B.PTEV) $9.52 ; M ~ 8.54 ; M^{*}(\mathrm{~B} . \mathrm{PTEV}) 2.56$ & II 30 & $12 \cdot 28$ \\
\hline 222 & M 9.44; F* (L.PTEV) 8.46; $F$ (R.PTEV) 9.50 & $7 \cdot 24$ & II I I I \\
\hline \multicolumn{4}{|l|}{ Calcaneo-valgus } \\
\hline 225 and 251 & $M($ B.CV) $10.55 ; F($ B.CV) 1.60 & $6 \cdot 27$ & $5 \cdot 23$ \\
\hline & $M$ (B.CV) $12.57 ; M^{*}$ (B.CV) 3.60 & $7 \cdot 36$ & II $\cdot 33$ \\
\hline 285 & $\mathrm{M}^{*}($ B.CV) $7.59 ; F($ R.CV $) 8.60$ & $6 \cdot 39$ & $3 \cdot 38$ \\
\hline 293 and 294 & $F($ B.CV $) 7 \cdot 54 ; \mathrm{F}_{\mathrm{I}} \cdot 57 ; F($ B.CV $) 7.58$ & $4 \cdot 27$ (R.CV) & $1 \cdot 29$ \\
\hline \multicolumn{4}{|c|}{ Metatarsus Varus } \\
\hline 302 and 335 & See TEV No. 15 & & \\
\hline 316 & $\mathrm{M}_{3.48} ; M$ (B.MV) $6.49 ; F(\mathrm{~B} . \mathrm{MV}) 5.53$ & $8 \cdot 26$ & II $\cdot 23$ \\
\hline 368 & See TEV No. 143 & & \\
\hline
\end{tabular}

Appendix B overleaf 


\section{APPENDIX B}

Findings in First-degree Relatives of Patients with Postural Talipes Equinovarus, Talipes Calcaneo-valgus, and Metatarsus Varus

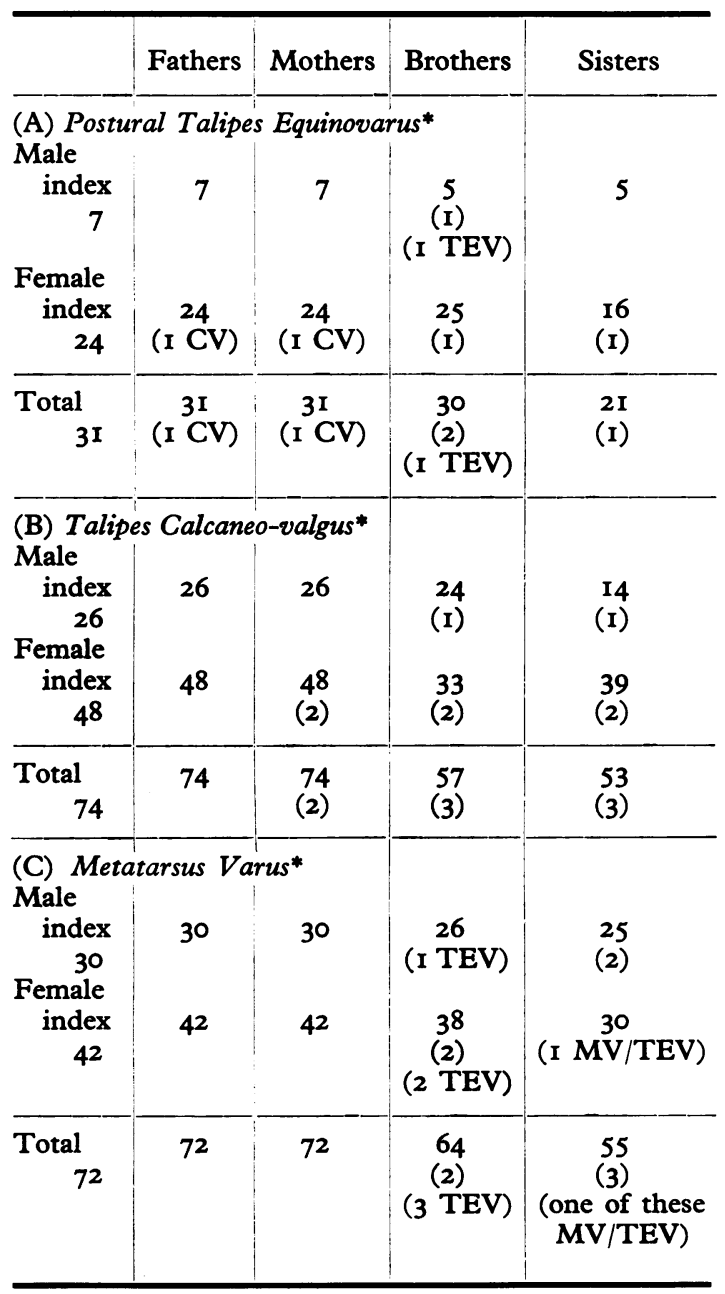

* First-degree relatives with same deformity are shown in parentheses.

In (A) talipes equinovarus and calcaneo-valgus deformities are also shown. In (C) talipes equinovarus deformities are also shown. 